\title{
Hydro and Wind Power Integration: A Case Study of Dargai Station in Pakistan
}

\author{
Shahbaz Awan ${ }^{1}$, Muhammad Ali ${ }^{1}$, Muhammad Asif ${ }^{2}$, Amjad Ullah ${ }^{1}$ \\ ${ }^{1}$ Electrical Engineering Department, NWFP University of Engineering \& Technology, Peshawar, Pakistan \\ ${ }^{2}$ Electrical Engineering Department, CECOS University of IT, Peshawar, Pakistan \\ Email: saanwal_2003@yahoo.com
}

Received May 25, 2012; revised June 27, 2012; accepted July 6, 2012

\begin{abstract}
Pakistan is facing acute energy crises since last few years. Due to shortage of fuel oil and its sky touching prices, it seems very uneconomical to generate electricity from fuel oil. In order to generate cheap electricity we have to rely on renewable energy resources. To address these challenges, wind power generation is among the popular options in the world which is now being considered in Pakistan as well. However unremitting change in wind speed from calm to stormy introduces real challenges. Storing wind energy in batteries during the periods of low demand seems an expensive option, especially when dealing with large scale power generation. Due to incessantly varying nature of wind speed, it is not feasible to rely only on wind power for cheap power production. Also, it is not thriftily possible to construct separate transmission line. However if we integrate wind power with hydro power, we can utilize the maximum possible transmission capacity. Existing hydro power station operating in that area or pumped storage scheme can be used. This paper is an attempt to analyze coordination of wind generation with hydro power in those areas of Pakistan where both wind and hydro power sources exist. In this paper, different issues have been analyzed taking case study of Dargai. This paper is first attempt in Pakistan about integration of wind and hydro power to draw some general conclusions and to point out some areas in which further research can be done.
\end{abstract}

Keywords: Wind Power Generation; Hydro Power Generation; Integration; Transmission Bottleneck

\section{Introduction}

The tremendous increase in the energy consumption in the world and conventional methods of energy production has led to severe environmental problems due to greenhouse gases emissions. Renewable energy sources have a key role in the reduction of air pollution, especially $\mathrm{CO}_{2}$ emission. Several energy sources which can be a good alternative for fossil fuel are solar, wind and ocean energy.

Since the independence of Pakistan, the primary power supplies from the conventional energy sources were not enough to meet the country's demand. In these days Pakistan is facing severe energy crisis. Power shortages started to appear since 2005 as load side infrastructure is tremendously increasing. The current installed capacity in the country is 19,500 MW and out which hydel production is only $6500 \mathrm{MW}$ and remaining significant portion of energy requirements are fulfill by thermal production either utilizing oil or gas. Power supplying agency in country is WAPDA and some part of it is shared by IPP's. Due to huge amount of prices raised in supply by utilizing furnace oil for production by IPP's, WAPDA has to pay an annual bill of Rs.425 billion to private agencies and as it fails to do so IPP's are producing much less electricity than their capacity.

Pakistan, in spite of the great potential of its indigenous energy resources, remains energy deficient and has to rely heavily on the imports of the petroleum products to satisfy its present day need. Now, there has been a growing interest, to explore of other energy resources. One reason is that the reserves of fossil fuels are not unlimited and at the present rate of use they would not last very long. Moreover, it has been conclusively proved that climate change, which has been resulting in global warming, is mainly caused by greenhouse gases emissions from power houses make use of the fossil fuels. However, another aspect that has come into sharp focus is that the developing countries can not afford to depend completely upon petroleum imports as they are marked by unpredictable price fluctuations. Considering the geological setup and geographical position, Pakistan has high potential of renewable energy sources, still now, which have not been effectively explored and developed. Wind energy source is one of them. Pakistan is also fortunate to have high speed winds in some major areas of 
population such as areas of KPK e.g., Dargai station. By using this source for production will add a lot to the final increase and mini grids launched and established will at least solve problems of many villages. This paper describes the prospects for the wind energy sources in Pakistan with the view to initiate the individual and collective efforts for the development of wind energy generation technology that is presently at zero.

\section{Related Work}

Pakistan has wind potential in Swat, Dargai (KPK), Shaheedgali (AJK) and Kalar Kahar (Punjab) [1]. The interest for coordination of wind power and hydro power has increased during the last few years. The saved water can be then used in times with no wind or when, for other reasons, hydro power is wanted [2]. With the interconnection of a number of power stations, the reliability of supply to the consumer is greater [3]. This recent topic of research is studied by many utilities (e.g. Vattenfall, Skeleftea Kraft, in Sweden, Hydro-Quebec, in Canada) as well as by research organizations (e.g. SINTEF in Norway, NTNU in Norway and VTT in Finland, INESC-Poto in Portugal, Universidad Carlos III de Mardid in Spain, Ecole des Mines de Paris in France, NTUA in Greece, etc.) [4]. European Union has set a binding target of $20 \%$ of demand to be covered by wind and other renewable energy resources by 2020 [4,5]. In Nordic countries system integration of wind energy influence not only domestic production, it influences the whole market area [6].

Pakistan has great wind and hydro power potential in northern regions. Shaheedgali, Bunji, Dargai are interesting places from coordination point of view.

\section{Problem Formulation}

The government of Pakistan realized the energy crises in Pakistan and decided to develop wind energy sources in the country. However power generation from wind introduces us with some new issues:

- There is continuous change in the wind speed and wind speed may be more when power demand is low, resulting in wind spillage.

- Like hydro power, wind speed follows seasonal variations.

- Wind plant can be established within a year while construction of transmission line takes 4 - 5 years.

- Due to low capacity factor, wind plants have to sit idle for most of the time, so it is not economical for us to construct separate transmission line for wind power transmission.

In order to address these challenges, we have to adopt different strategies. When wind speeds are more than load demand, we can store extra energy in batteries.
However when we think about large scale wind farms it seems to be uneconomical.

Pakistan has great hydel power potential, since largest rivers can be found here. Almost all hydro power is concentrated in KPK, AJK, Gilgit Baltistan and northern Punjab. These regions of the country also have good wind conditions and therefore interesting for wind power projects.

Thus during the period of high speed winds, hydro power plant having some sort of water storage or pump storage plant can be used for this purpose. When wind speeds are high we can generate maximum power from wind, and storing water for future power generation during the period of low wind speed. The idea behind using wind power in a hydro power is to use wind power when it exists. In cases of limited transmission or limited request of power, hydro power production is decreased. Since water has also seasonal variations therefore this integration is a best option for economic power generation. Wind power can also be used to meet the demand of the local load centre. Due to continuously varying nature of wind speed, it is not possible to rely only on wind power for cheap power production. Also, it is not economical possible to construct separate transmission line. However if we integrate wind power with hydro power we can utilize the maximum possible transmission capacity. So in future wind hydro coordination may be a good option to meet system demand.

\section{Emerging Trends}

European countries are successfully working on coordination of wind and hydro power. As it has been mentioned that continuously varying nature of wind speed makes impossible rely only on wind power for cheep power production. Also, it is not economically justifiable to construct separate transmission line. However if we integrate wind power with hydro power we can utilize the maximum possible transmission capacity.

More wind implies more variability seen in power systems, depending on the load variability and forecast errors. Hydro has flexibility in varying production level [7]. Coordination of Hydro power and Wind power can be beneficial for both the wind power utility and hydro power utility [8].

When wind speeds are high we can generate maximum of power during this period and storing water for future generation during the period of low wind speed. Like wind, water has also seasonal variations; therefore this integration is a best option for economic power generation. At least, wind power can be used to meet the demand of the local load centre.

Figure 1 shows the simplest integration concept.

This integration technique as shown in Figure $\mathbf{1}$ can 


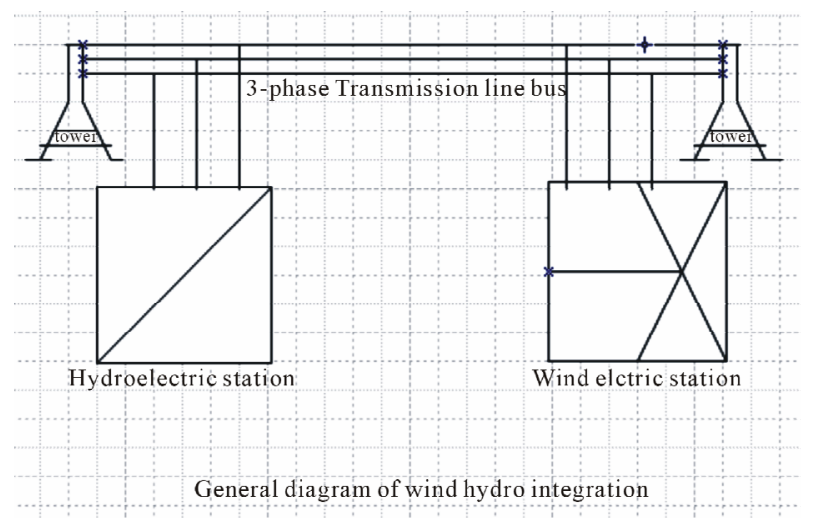

Figure 1. General diagram of wind hydro integration.

be called sharing of transmission line.

Another method of coordination is to use wind speed to drive water pump in pump storage hydro power plant.

\subsection{Integrating Wind and Hydro at Dargai}

Dargai is a town of Malakand division having great hydro power potential as well as wind power potential. We will analyze the possibilities and different strategies for integrating hydro power with wind power at this site in different steps.

This is a general analysis of economical power generation by coordinating hydro power with wind power. All wind data and its graphical representation is for 50 meter height. Results of this kind of coordination may change for different sites and also depends upon the purpose or requirements for which this integration is used.

\subsubsection{Wind Frequency Distribution}

The best conditions for building Wind farms (WF) are usually in remote areas with low population density [9], [4]. Pakistan Meteorological Department (PMD) conducted a survey of about 42 wind power potential sites and collected their wind data. One of Wind Power potential sites of this phase-II was Dargai which has good wind conditions.

Table 1 gives the summary of wind frequency distribution at Dargai during the twelve months from Feb-08 to Jan-09. Figure 2 is the graphical representation of Table 1 and it shows the wind frequency distribution at Dargai from Feb-08 to Jan-09.

Annual wind frequency data given in Table 1 has been collected at $50 \mathrm{~m}$ height by Pakistan Meteorological Department (PMD). Wind frequency distribution shows that during $31 \%$ of the time wind speed is $5 \mathrm{~m} / \mathrm{s}$ or above. This indicates wind power potential in this area.

\subsubsection{Proposed Wind Power Generation}

At height of 50 meters, average monthly wind speed is shown in Figure 6. We see during twelve months from
Table 1. Annual wind frequency distribution [10].

\begin{tabular}{cccccccc}
\hline $\mathrm{V} \mathrm{m} / \mathrm{s}$ & Hours & $\mathrm{V} \mathrm{m} / \mathrm{s}$ & Hours & $\mathrm{V} \mathrm{m} / \mathrm{s}$ & Hours & $\mathrm{V} \mathrm{m} / \mathrm{s}$ & Hours \\
\hline 1 & 1024 & 7 & 669 & 13 & 23 & 19 & 1 \\
2 & 1199 & 8 & 713 & 14 & 8 & 20 & 1 \\
3 & 1302 & 9 & 592 & 15 & 4 & 21 & 1 \\
4 & 896 & 10 & 396 & 16 & 2 & 22 & - \\
5 & 556 & 11 & 218 & 17 & 1 & 23 & - \\
6 & 529 & 12 & 85 & 18 & 1 & 24 & - \\
\hline
\end{tabular}

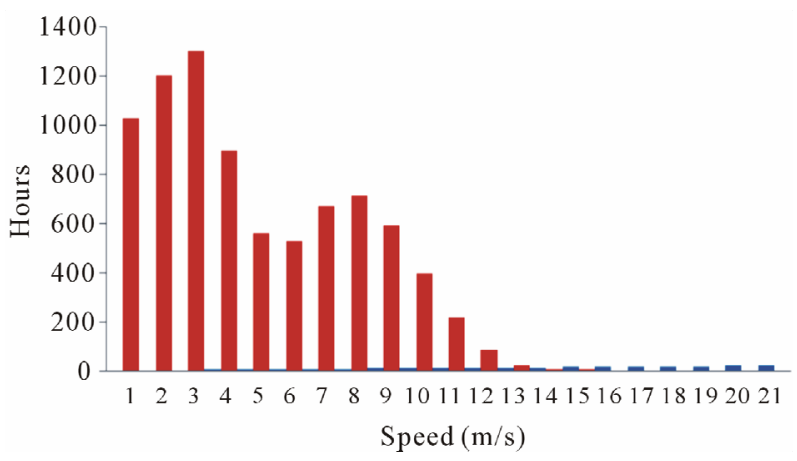

Figure 2. Wind distribution at Dargai from Feb-08 to Jan-09.

Feb-2008 to Jan-2009, monthly average wind speed is more in winter months than in summer months.

Proposed wind generated electric power output at Dargai has been estimated by using the single $600 \mathrm{KW}$ wind turbine bonus 600/44. The cut in wind speed is that speed at which wind turbine starts generation. Cut in speed of this turbine is $3 \mathrm{~m} / \mathrm{s}$. Table 2 shows the proposed monthly wind power generation at 50 meters. It is not the total power generation of this site and is meant for showing power potential using single $600 \mathrm{KW}$ turbine.

Figure 3 is graphically representation of Table 2 .

Since capacity factor of wind farm is not enough, it is uneconomical to construct a large commercial wind farm. However if we integrate wind power with hydro power we can solve many problems.

\subsubsection{Dargai Grid}

There is $132 \mathrm{KV}$ grid at Dargai, a town of Malakand Division. Figure 4 shows the single line diagram of Dargai grid station. It shows that Drgai grid is supplied by 20 MW Dargai hydel power station (HPS) along with 81 MW Malakand-III HPS. However, due to aging effect capability of Dargai HPS has been reduced to $18 \mathrm{MW}$. Malakand-III is about $4 \mathrm{~km}$ away from Dargai grid and is operating under SHYDO-provincial government.

Generation voltage of Dargai Power Station is $11 \mathrm{KV}$. In order to connect it with $132 \mathrm{KV}$ Dargai Grid, it is then 
Table 2. Proposed power generation of a single $600 \mathrm{KW}$ wind turbine at Dargai.

\begin{tabular}{cccc}
\hline Month & Input W/m & Output W/m & KWh/Month \\
\hline January & 171 & 62 & 70,220 \\
February & 256 & 82 & 87,010 \\
March & 218 & 76 & 85,777 \\
April & 151 & 53 & 57,490 \\
May & 157 & 52 & 58,787 \\
June & 66 & 24 & 25,930 \\
July & 52 & 19 & 20,989 \\
August & 74 & 26 & 29,025 \\
September & 143 & 49 & 53,332 \\
October & 196 & 66 & 74,800 \\
November & 238 & 79 & 86,362 \\
December & 213 & 76 & 85,460 \\
Annual & 150 & 52 & 696,663 \\
\hline
\end{tabular}

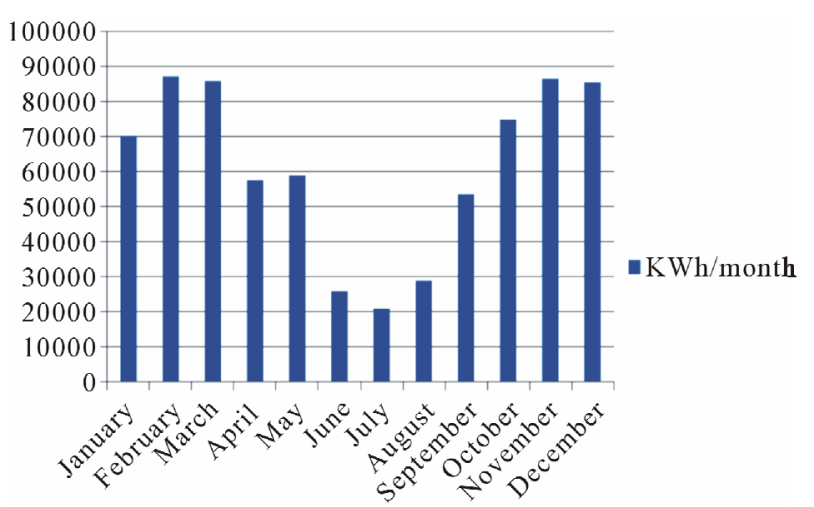

Figure 3. Proposed generation of a $600 \mathrm{KW}$ turbine at Dargai.

stepped up to $132 \mathrm{KV}$ by power transformer. Generation voltage of Malakand-III is also $11 \mathrm{KV}$, which is stepped up to $132 \mathrm{KV}$, and transmitted to Dargai grid by two 132 KV transmission lines. From this Dargai grid, one 132 $\mathrm{KV}$ transmission line goes to $220 \mathrm{KV}$ Mardan grid and second $132 \mathrm{KV}$ transmission line is connected with 132 Chakdara grid. Capacity of each transmission line is 87 MW.

Energy import and export occur according to grid demand. Presently maximum export could be 99 MW (18 $\mathrm{MW}+81 \mathrm{MW}$ ). There is further room of $75 \mathrm{MW}$ power to be transmitted from the both $132 \mathrm{KV}$ transmission lines collectively. There are four $11 \mathrm{KV}$ feeders emanating from $132 \mathrm{KV}$ Dargai grid to meet local load. Power transfer capacity of these four feeders is about $20 \mathrm{MW}$. There is also $66 \mathrm{KV}$ grid transformer at Dargai grid from which two $11 \mathrm{KV}$ feeders emanate to supply locality. These two $11 \mathrm{KV}$ feeders can meet about $8 \mathrm{MW}$ Local load. Power transfer capacity of these six $11 \mathrm{KV}$ feeders shows that there is maximum $28 \mathrm{MW}$ local load [11].

\subsubsection{Using the Available Transmission Capacity}

The capacity of each transmission line is $87 \mathrm{MW}$, thus a total transmission capability of both $132 \mathrm{KV}$ transmission lines is $174 \mathrm{MW}$. If Malakand-III and Dargai hydro power stations operate at their maximum installed capacity, there is further room of $75 \mathrm{MW}$ power to be transmitted through both these lines collectively. So wind power can easily be transmitted.

However if 22 MW Jabban power house, which is about $7 \mathrm{~km}$ from Dargai grid is synchronized, there is again room of $53 \mathrm{MW}$ for power transmission through these two $132 \mathrm{KV}$ transmission line. However if $53 \mathrm{MW}$ capacity is reserved for future hydel generation, wind power can be used to met local load since $11 \mathrm{KV}$ feeders can carry load of about $30 \mathrm{MW}$.

\subsubsection{Integrating Wind Power with Hydro Power}

In case of future hydel power extension and when maximum hydro power is being transferred, what will be the solution?

In order to increase transmission capacity, transmission system reinforcement is time consuming and expensive option. It is obvious that it normally will not be optimal to remove a bottleneck completely. Thus some other alternatives are necessary to handle the congestion problems and make large scale integration of wind power possible. One possibility is the curtailment of excess wind energy, when transmission is congested. Another alternative to transmission system reinforcement is to store excess wind energy during the congestion situations [12].

Battery storage or transmission reinforcement is expensive option. On the other hand, we use the simple integration technique, which is to store water when wind speeds are high and to use stored water for electric power production when wind speeds are low. Hydro power station either it is dam type, or without dam, there is always some storage at intake such as fore bay to store water temporarily and to maintain power channel level. This is the main idea behind integration.

Figure 5 shows the diurnal wind speed variations at Dargai for 12 months (Feb-08 to January-09). The wind speed is generally lower during noon and in the evening it starts picking up and reaches maximum around 6 a.m. which is about $4.6 \mathrm{~m} / \mathrm{s}$ and $6.5 \mathrm{~m} / \mathrm{s}$ at 30 meters and 50 meters height respectively.

Thus when wind speed are high we can generate maximum possible electricity from wind and thus decreasing generation from hydro power plant and storing 


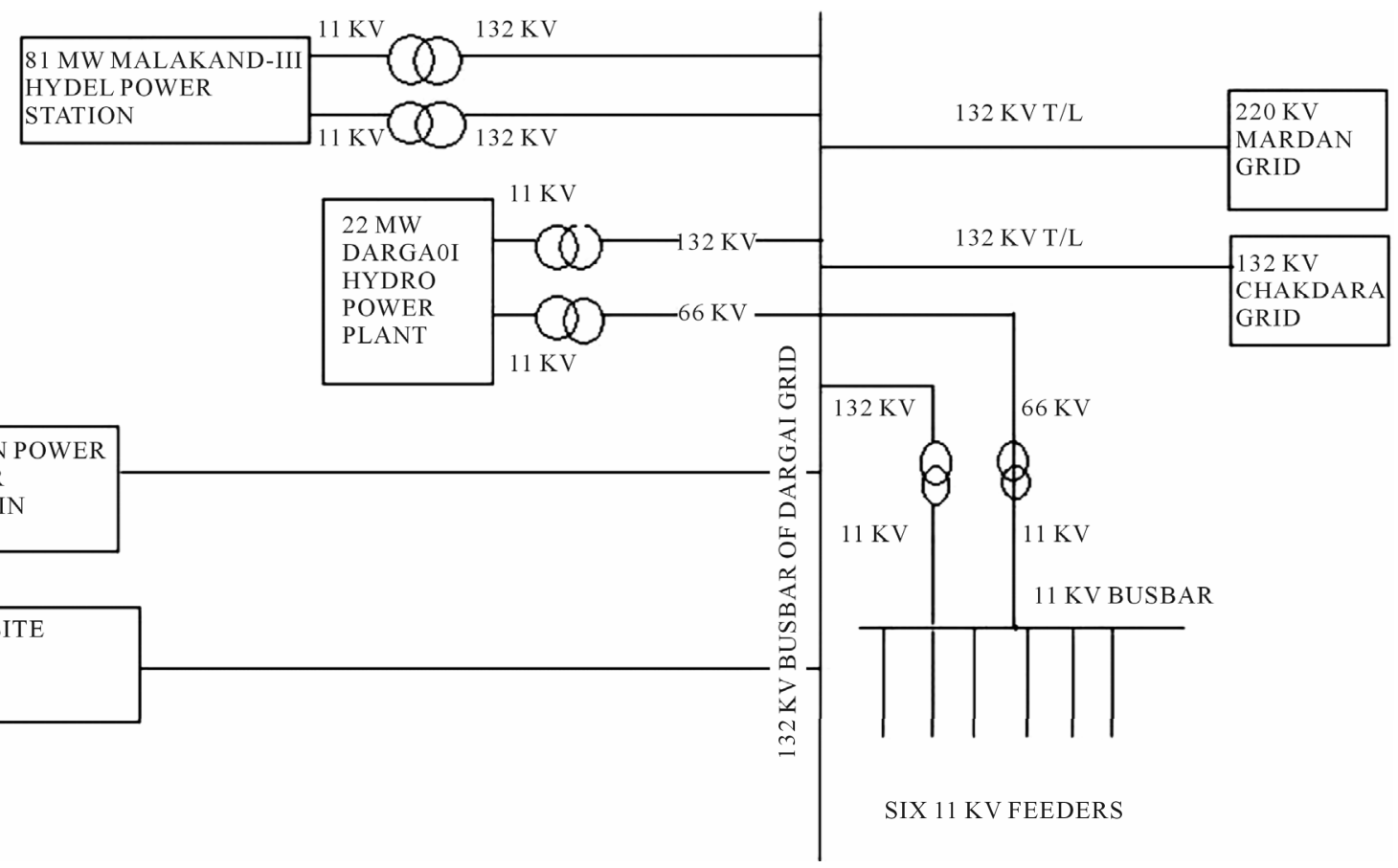

Figure 4. Single line diagram of Dargai grid.

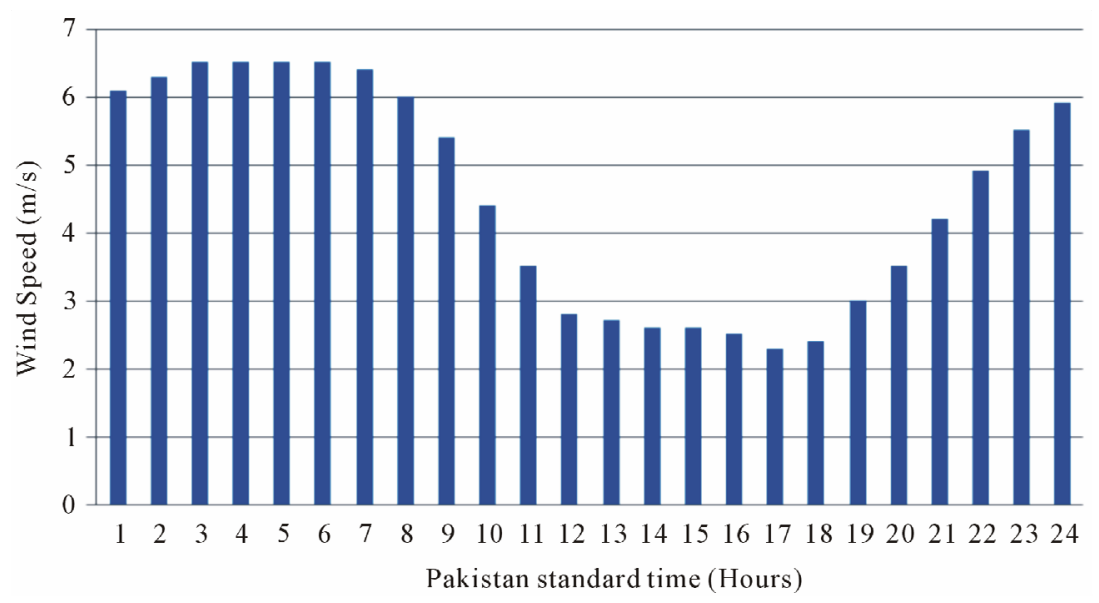

Figure 5. Hourly wind speed variations at Dargai (Feb08-Jan09).

water for future periods when wind speeds are not enough to generate electricity.

\subsubsection{Transmission Bottleneck at Dargai}

How can we avoid transmission bottleneck type problems at Dargai? Simply we can use the techniques discussed in the previous section. Wind power production peaks do not always occur during the period of insufficient transmission capacity. Therefore reinforcing a transmission network in order to remove bottleneck completely cannot be economically justified [13]. If we look at the monthly average speed of Dargai wind site, we find the answer of the question. "Is there any chance of transmission bottleneck at Dargai?” There will be a rare chance of transmission bottleneck, because maximum wind speed is in winter months. Figure 6 shows that wind occurs more in winter than summer months at Dargai. Everybody knows that water is more in summer months; thus there is no chance of transmission bottleneck at Dargai.

\subsubsection{Correlation}

Climate is an important issue regarding hydro power generation. Precipitation plays an important role. Year 2010 was a wet year. That is why hydro power production was maximum. Power demand also depends upon weather. Maximum demand occurs in Pakistan during summer months and during this period, hydro power 


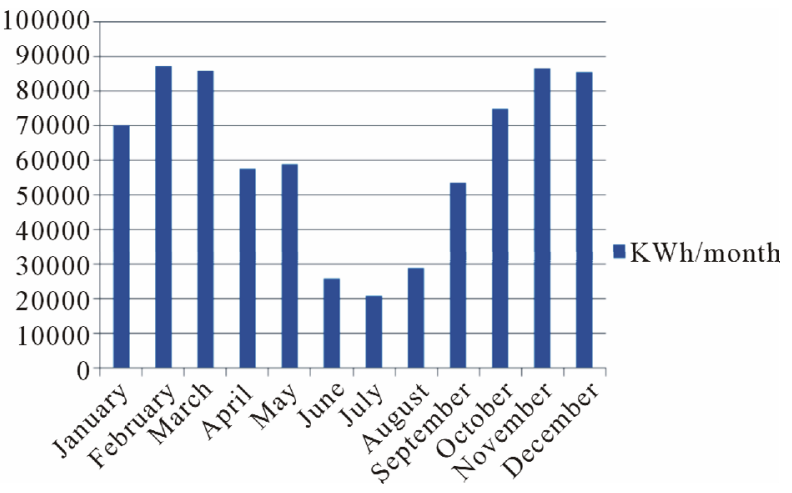

Figure 6. Monthly average wind speed at Dargai.

generation is more. Also that year, summer season started very early during the mid of March. In winter months, less power demands occur as compared to summer months. Hydro power production decreases during the winter months.

However if we look at present conditions of Pakistan, we face short fall of energy throughout the year. That is why we have to need of other renewable resources, thus as far as Dargai is concerned wind conditions are good during winter months.

\subsubsection{Pump Storage Scheme}

Wind power may fluctuate significantly within a week, a day, or even hours [14]. To compensate it, we can use another technique of hydro-wind coordination where a water pump coupled with windmill is used to pump water from low level reservoir constructed at down stream of hydro power station (HPS) to its high level reservoir/ pond. When demand of electric energy is more, this stored water can be utilized to generate electricity. Water pumps are less sensitive to wind speed variations than electric generator [15] and are also cheaper than electric equipments. Thus hybrid wind hydro power strategy seems to be an economical advantageous.

Application of pump storage to facilitate wind power integration has been analyzed from several prospective [16]. Normally head required for pump storage scheme should not be less than $150 \mathrm{ft}$; otherwise this scheme cannot be economically feasible. So for as Jaban site is concerned, its head of $251 \mathrm{ft}$ makes it suitable for pump storage scheme [11]. These sources of energy currently provide only a small amount of energy in worldwide [17], although they are expected to play a greater role in future energy provision. Furthermore, indiscriminate use of wood as fuel leads to deforestation with consequent environmental hazards and inefficient burning of fuel wood leads to an increase in indoor air pollution [18].

\section{Conclusion}

The article focuses on two basic integration strategies of wind hydro coordination in Pakistan. In this thesis, we studied that it is possible to coordinate wind and hydro power in Pakistan for cheap electricity throughout the year. Maximum power transfer from same transmission line is very beneficial for grid owner. This integration with proper planning will also be profitable for hydro power plant owner as well as for wind farm power plant owner. This association results in the reduction of wind spillage. Due to non utilization of fuel oil, not only the electricity tariff will be reduced but it will also help in the reduction of environmental pollution. Fuel oil saving is another advantage. Secondly we gave touch to pumped storage scheme. Since due to limited wind data it was not possible to cover different issues, however for future work with more data it will be possible to provide integration at more sites with more integrating strategies and in more details.

\section{REFERENCES}

[1] www.aedb.org.pk

[2] A. Jaderstrom, "Coordinated Regulation of Wind Power and Hydro Power with Separate Ownership,” Master's Degree Project, Department of Electrical Engineering, Royal Institute of Technology, Stockholm, 2004.

[3] M. V. Deshpande, "Elements of Electrical Power System Design,” 3rd Edition, Wheeler Publishers, New Delhi, 1985, p. 342.

[4] J. Matevosyan, "On the Coordination of Wind and Hydro Power," The International Workshop on Large Scale Integration of Wind Power into Power Systems as well as on Transmission Networks for Offshore Wind Farms, Sweden, 2008.

[5] J. Matevosyan, Z. Bockarjova, M. Zima and L. Soder, "Sharing of Profit from Coordinated Planning and Bidding of Hydro and Wind Power," IEEE Transaction on Power Systems, Vol. 25, No. 3, 2009, pp. 1663-1673.

[6] K.-O. Vogstad, H. Holttnen, A. Botterud and J. O. G. Tande, "System Benefits of Coordinating Wind Power and Hydro Power in Deregulating Market," Proceeding of Wind Power for the 21st Century, Kasel, 2000.

[7] H. Holttnen, "Wind Hydro Integration on a Large Hydro System," UWIG Wind Hydro Integration Workshop, Portland, 21 March 2007

[8] J. Matevosyan, M. Olsson and L. Soder, "Hydro Power Planning Coordinated with Wind Power in Areas with Congestion Problems for Trading on the Spot and the Regulating Market,” Electrical Power Systems Research, Vol. 79, 2009, pp. 39-48. doi:10.1016/j.epsr.2008.05.019

[9] M. Ali, J. Matesovyan, J. V. Milanovic and L. Soder, "Effect of Wake Consideration on Estimated cost of Wind Energy Curtailment," 8th International Workshop on Large Scale Integration of Wind Power, Bremen, 14-15 October 2009.

[10] A. Hayat and J. Ahmad, “A Study of Wind Power Potential at Dargai,” Pakistan Meteorology Department Tech- 
nical Report No. PMD 02/2009, 2009

[11] I. Shah, “Operating Hydro Power Stations of KPK," Report of Hydro Planning WAPDA Department, Lahore, 2010.

[12] J. Matevosyan, "Wind Power Integration in Power System with Transmission Bottleneck," Royal Institute of Technology, Stockholm, 2007.

[13] M. Olsson, J. Matevosyan and L. Soder, "Short Term Hydro Power Planning Coordinated with Wind Power in Areas with Cogestion Problems,” Proceedings of 2006 International Workshop on Large Scale Integration of wind Power and Transmission Networks for Offshore Wind Farms, Delft, 26-28 October 2006.

[14] K.-O. Vogstad, "Utilizing the Complementary Characteristics of Wind Power and Hydro Power through Coordinate Hydro Production Scheduling Using EMPS Model,” Proceeding of Nordic Wind Energy Conference, Trond- heim, 13-14 March 2000.

[15] W. Youssef, "Hybrid Wind-Hydro Power Plant,” New York, 2000.

[16] S. Papaefthimiou, E. Karamanou and S. Papathanassiou, "Operating Policies for Wind pumped-Storage Hybrid Power Stations in Islands Grids,” IET Renewable Power Generation, Vol. 3, No. 3, 2009, pp. 293-307. doi:10.1049/iet-rpg.2008.0071

[17] A. Saket and A. Etemad-Shahidi, "Wave Energy Potential along the Northern Coasts of the Gulf of Oman," Iran Renewable Energy, Vol. 40, No. 1, 2012, pp. 90-97. doi:10.1016/j.renene.2011.09.024

[18] N. A. Zaighama, Z. A. Nayyarb and N. Hisamuddin, "Review of Geothermal Energy Resources in Pakistan," Renewable and Sustainable Energy Reviews, Vol. 13, No. 1, 2009, pp. 223-232. doi:10.1016/j.rser.2007.07.010 